\title{
Efektifitas Penarikan Retribusi Parkir Pasar Ditinjau Dari Kualitas Pelayanan
}

\author{
Benny Andriawan \\ Dinas Perindustrian dan Perdagangan Kota Blitar \\ Email: benny.andriawan2@gmail.com
}

\begin{abstract}
One of the main components of Regional Original Revenue is regional retribution. Thus in order to improve the ability of Regional Original Revenue, one of them can be achieved by increasing regional revenues from the regional retribution sector. The service quality received by market users as retribution payers will affect the achievement of market retribution targets. The thesis purpose was to analyze the effect of the service quality of Industry and Trade Departement on the effectiveness of withdrawing market parking retribution in Blitar City.

The research design was intended to test the research bypothesis and to interpret the causal relationship between independent variables and dependent variables, namely the variable service quality of the market service $(X)$ and the effectiveness of withdrawing market parking retribution (Y). The population was the people who use parking on the market of Blitar City which amounts to an average of 880 people every day. The sample size was 90 respondents with Proportionate Stratifeid Sampling technique. The research instrument used a questionnaire and has been tested for validity and reliability testing. To test or measure the effect of exogenous variables on the endogenous variable used rimple regression analysis.

The results showed that there was an effect of the service quality of Industry and Trade Departement affected the effectiveness of withdrawing the parking market retribution in the city of Blitar. The tvalue was 20,859 that higher than t-table value amount 1,980. The coefficient of determination between the service quality variable of the Trade and Industry Departement (X) with the variable effectiveness of the withdrawal of the market parking retribution $(Y)$ is $(0.912)^{2}=0.832$. This figure indicates that there was $83,2 \%$ changes to variable $Y$ explained or determined by variable $X$. Based on the results, it is expected that the Trade and Industry Departement had improve the quality and quantity of market facilities and infrastructure and parking, so that traders can run their business maximally and consumers are comfortable to shop in traditional markets.

Keyword: service quality, effectiveness of the withdrawal of the market parking retribution
\end{abstract}

\section{A. Latar Belakang Teoritis}

Salah satu masalah yang selama ini mewarnai penyelenggaraan pemerintahan daerah adalah masalah rendahnya tingkat kemampuan keuangan daerah yang kemudian menimbulkan ketergantungan keuangan yang relatif tinggi dari pemerintah daerah terhadap pemerintah pusat. Pada masa pemerintahan orde baru, model ketergantungan keuangan yang relatif tinggi dari daerah kepada pemerintah pusat ini telah dijadikan salah satu strategi untuk mengendalikan daerah secara sentralistik. Fenomena ketergantungan keuangan yang relatif tinggi tersebut antara lain ditunjukkan oleh relatif kecilnya kontribusi Pendapatan Asli Daerah (PAD) terhadap keseluruhan pendapatan daerah. Tingkat kemandirian keuangan daerah merupakan salah satu pilar yang sangat penting dalam rangka penyelenggaraan pemerintahan dan pembangunan di daerah. Ini mengandung arti bahwa kemandirian keuangan atau pembiayaan pemerintah daerah merupakan hal yang sangat penting bagi pelaksanaan otonomi daerah.

Beranjak dari kenyataan di atas, maka salah satu hal yang harus dilakukan untuk memperlancar penyelenggaraan pemerintahan daerah adalah meningkatkan kemandirian daerah dalam menyediakan kebutuhan pendanaan penyelenggaraan pembangunan dan pemerintahan di daerah. Salah satu cara yang dapat ditempuh untuk meningkatkan kemandirian keuangan pemerintah daerah, antara lain dapat ditempuh dengan jalan mengupayakan peningkatan Pendapatan Asli Daerah (PAD). Hal ini didasari oleh argumentasi bahwa diantara berbagai sumber keuangan yang diterima oleh pemerintah daerah dalam penyelenggaraan pemerintahan dan pembangunan daerah, sumber penerimaan dari Pendapatan Asli Daerah merupakan sumber yang otoritas penggunaannya berada sepenuhnya di bawah kendali Pemerintah Daerah bersama-sama dengan Dewan Perwakilan Rakyat Daerah yang secara formal 
menjadi merupakan wakil rakyat. Ini artinya untuk menunjang keberhasilan otonomi daerah yang antara lain dicirikan oleh derajat kemandirian yang tinggi dari pemerintah dan masyarakat di daerah, maka sumber keuangan dari sektor Pendapatan Asli daerah adalah sektor yang paling tepat dalam pelaksanaan otonomi daerah. Menurut Undang-Undang Nomor 33 tahun 2004 tentang Perimbangan Keuangan antara Pemerintah Pusat dan Daerah, timbul hak dan kewajiban daerah yang dapat dinilai dengan uang, sehingga perlu dikelola dalam pengelolaan keuangan daerah. Sumber-sumber Pendapatan Asli Daerah dirinci sebagai berikut: 1) hasil pajak daerah; 2) hasil retribusi daerah; 3) hasil perusahaan milik daerah dan hasil pengelolaan kekayaan daerah lainnya yang dipisahkan ; dan 4) lain-lain pendapatan asli daerah yang sah.

Salah satu komponen pokok dari Pendapatan Asli Daerah adalah retribusi daerah. Dengan demikian dalam rangka meningkatkan kemampuan Pendapatan Asli Daerah (PAD), salah satunya dapat ditempuh dengan jalan meningkatkan penerimaan daerah dari sektor retribusi daerah. Semakin besar penerimaan daerah dari sektor retribusi daerah, semakin besar pula kemungkinan daerah untuk meningkatkan tingkat kemandirian keuangan dalam pengelolaan pemerintahan dan pembangunan di daerah.

Sekalipun disadari tentang arti penting pendapatan asli daerah, termasuk retribusi daerah di dalamnya, namun sebagaimana dikemukakan sebelumnya, dalam kenyataannya kemampuan keuangan daerah dari sumber pendapatan asli daerah selama ini belum dapat diandalkan sebagai sumber pembiayaan penyelenggaraan pemerintahan dan pembangunan di daerah. Penelitian yang dilakukan Iskandar (dalam Kuncoro, 1995 : 9) menyimpulkan hasil bahwa dari periode tahun 1984/1985 sampai dengan tahun 1990/1991 rata-rata kemampuan Pendapatan Asli Daerah Kabupaten dan Kota dalam membiayai penyelenggaraan pemerintahan dan pembangunan hanya sekitar $15,4 \%$ dari keseluruhan biaya yang dibutuhkan atau pendapatan daerah.

Kondisi ketergantungan yang tinggi dalam hal keuangan yang dicerminkan oleh relatif kecilnya kontribusi PAD terhadap keseluruhan pendapatan daerah juga terjadi di
Pemerintah Kota Blitar Propinsi Jawa Timur. Pada tahun 2016 Pendapatan Asli Daerah Kota Blitar sebesar 8,44 Milyar Rupiah, atau sekitar 2,98\% dari keseluruhan pendapatan daerah sebesar 283 Milyar Rupiah. Pada tahun 2017 penerimaan PAD mengalami peningkatan menjadi 9,23 Milyar Rupiah atau sebesar $2,77 \%$ dari keseluruhan pendapatan daerah sebesar 333 Milyar Rupiah. Namun secara persentase kontribusi PAD mengalami penurunan menjadi $0,21 \%$ dari tahun sebelumnya. Data ini menunjukkan masih relatif rendahnya kontribusi Pendapatan Asli Daerah terhadap keuangan daerah secara keseluruhan.

Lebih lanjut dari data yang ada pada Kantor Dinas Pendapatan Daerah Kota Blitar, diketahui bahwa dari keseluruhan PAD pada tahun 2016 sebesar 8,44 milyar rupiah tersebut, sekitar 57,46\% atau sebesar 4,85 milyar rupiah diperoleh dari kontribusi sektor retribusi daerah, sisanya dari sektor pajak daerah dan laba BUMD. Pada tahun 2017 kontribusi retribusi daerah terhadap keseluruhan PAD sebesar 9,23 milyar, sekitar $59,40 \%$ atau sebesar 5,48 milyar rupiah. Hal ini tentunya mengalami peningkatan sebesar $1,94 \%$ dari tahun sebelumnya. Retribusi pasar menjadi salah satu andalan untuk meningkatkan PAD Kota Blitar. Retribusi pasar terdiri dari retribusi jasa usaha, retribusi pertokoan dan retribusi parkir.

Dalam kaitan ini perlu dikemukakan tentang strategis dan potensialnya retribusi pasar terutama retribusi parkir pasar bagi peningkatan Pendapatan Asli Daerah. Dalam hal ini walaupun besarnya kontribusi parkir pasar masih rendah dibanding dengan retribusi pasar yang lain, namun menurut data tercatat bahwa retribusi parkir pasar selama dua tahun berturut-turut (2016-2017) selalu mengalami kenaikan, sementara retribusi pasar yang lain walaupun memberikan kontribusi terbesar namun selama dua tahun berturut-turut justru cenderung tetap atau cenderung mengalami penurunan. Ini menandakan betapa potensialnya retribusi parkir pasar bagi pendapatan asli daerah. Namun demikian, pengelolaan retribusi pasar selama ini dapat dikatakan belum optimal, sehingga dengan sendirinya juga mengakibatkan rendahnya efektifitas pendapatan asli daerah, terutama dari retribusi parkir pasar tersebut. Retribusi 
parkir pasar sendiri mengacu pada Perda No. 6 dan Perda No. 7 Tahun 2013.

Pencapaian target retribusi parkir pasar menurut pengamatan awal penulis tidak terlepas dari belum optimalnya pelayanan yang dilakukan oleh Dinas Perdagangan dan Perindustrian Kota Blitar. Berdasarkan data dan informasi dari Dinas Perdagangan dan Perindustrian Kota Blitar bahwa alokasi dana untuk setiap tahun masih minim dibandingkan dengan kondisi pasar yang semakin tahun perlu ditingkatkan baik penampilan fisik maupun pelayanannya. Alokasi dana untuk setiap tahun anggaran hanya dipergunakan untuk biaya operasional.

Alokasi dana untuk pasar yang minim secara operasional belum mampu meningkatkan kinerja pelayanan Dinas Perdagangan dan Perindustrian Kota Blitar saat ini, sementara jumlah pasar yang menjadi target PAD Parkir Pasar di Kota Blitar saat ini adalah 7 pasar. Masih minimnya alokasi dana pemeliharaan sarana dan prasarana pasar tersebut turut mempengaruhi kesigapan para petugas dalam menanggapi keluhan para pedagang dan konsumen pasar terutama pada perbaikan sarana penunjang khususnya sarana parkir yang memadai.

Belum optimalnya pelayanan tersebut, sedikit banyaknya menurut penulis berpengaruh terhadap efektifitas penarikan retribusi parkir pasar. Hal ini dapat dimaklumi, karena pada dasarnya retribusi adalah pembayaran secara sukarela atas jasa, layanan dan atau pemakaian fasilitas yang diberikan oleh pemerintah daerah. Oleh karena itu kualitas pelayanan yang diterima oleh para pengguna pasar sebagai pembayar retribusi akan berpengaruh terhadap pencapaian target retribusi pasar. Kemudian yang sering mendapat tanggapan dari pedagang adalah kenaikan tarif retribusi parkir pasar yang tidak diikuti oleh perbaikan pelayanan parkir pasar yang memadai, bahkan menimbulkan keluhan dari para pedagang dan konsumen pasar.

Atas dasar latar belakang pemikiran di atas, penulis terdorong untuk melakukan penelitian dan menuangkannya dalam karya ilmiah dalam bentuk tesis dengan judul: Pengaruh Kualitas Pelayanan Disperindag Terhadap Efektifitas Penarikan Retribusi Parkir Pasar di Kota Blitar.

\section{Kualitas Pelayanan Publik}

Tjiptono (2011: 76) mendefinisikan konsep kualitas sebagai berikut : Kualitas adalah suatu standar yang harus dicapai oleh seseorang atau kelompok atau lembaga atau organisasi mengenai kualitas sumber daya manusia, kualitas cara kerja, proses dan hasil kerja atau produk yang berupa barang dan jasa. Pengertian yang diberikan oleh Triguno tersebut menunjukkan bahwa konsep kualitas berkaitan erat dengan pencapaian standar atau target yang diharapkan. Dalam pelaksanaan pelayanan berkualitas menurut Thoha (1998) bahwa : Untuk meningkatkan kualitas pelayanan publik, organissai publik (birokrasi publik) harus mengubah posisi dan peran (revitalisasi) dalam memberikan layanan publik.

DeVrye (dalam Saefullah, 1999 : 9-10) mengemukakan 7 (tujuh) strategi menuju keberhasilan pemberian pelayanan. Ketujuh strategi tersebut istilahnya berawal huruf dari masing-masing kata Service yang terdiri atas :

1. Self Esteem, dimaksudkan sebagai upaya memberikan nilai pada diri sendiri untuk memahami keadaan yang dimiliki secara internal, termasuk di dalamnya memberikan perhatian terhadap pegawai dan bersikap keteladanan bagi mereka;

2. Exceed Expectation, yaitu memenuhi harapan-harapan dan berusaha melebihi apa yang telah dijanjikan, dengan kata lain, jangan terjadi sebaliknya, apa yang dijanjikan lebih rendah kenyataannya dari janji tersebut;

3. Recover, di dalamnya termasuk tanggapan atas keluhan langganan dan mencari tahu apa yang dipikirkan konsumen tentang perusahaan;

4. $V$ ision, di dalamnya termasuk pemikiran tentang rencana yang matang mengenai pelayanan jangka panjang, termasuk memperhitungkan penilaian langganan sehingga terus menjadi perhatian perusahaan;

5. Improve, yakni berusaha untuk melakukan peningkatan secara berencana dan terus menerus sehingga mempunyai kemampuan untuik bersaing dan memenangkan persaingan;

6. Care, menaruh perhatian yang cukup terhadap langganan sehingga mereka merasa dihargai dan betul-betul 
diperhatikan, sekalipun mungkin sebagian diantaranya hanya basa basi.

7. Empower, yakni memberdayakan pegawai dengan memberikan latihan, menanamkan rasa tanggung jawab, percaya pada kemampuan diri serta menggugah utnuk memberikan respon.

\section{Efektivitas Penarikan Retribusi Pasar}

Syamsi (1988: 6) memberikan penjelasan tentang konsep efektivitas dengan membandingkannya dengan konsep efisiensi sebagai berikut Pengertian efektivitas berbeda dengan efisiensi. Efisiensi diterjemahkan dengan "daya guna", sedangkan efektivitas diterjemahkan dengan "hasil guna". Efektivitas (hasil guna) ditekankan pada efek atau hasilnya, dan tanpa atau kurang mempedulikan pengorbanan yang perlu diberikan untuk memperoleh hasil tersebut. Sedangkan efisiensi (daya guna) penekanannya disamping pada hasil yang ingin dicapai, juga pada besarnya pengorbanan untuk mencapai hasil tersebut perlu diperhitungkan.

Kelima dimensi efektivitas yaitu :

\section{Produktivitas (Productivity)}

Menurut Gibson, dkk (1986: 34) dimensi produktivitas berkaitan dengan kemampuan untuk menghasilkan jumlah keluaran barang atau jasa. Dikaitkan dengan penarikan retribusi pasar, maka dimensi produktivitas ini berkaitan dengan kemampuan untuk menghasilkan penerimaan retribusi sebanyak mungkin sesuai dengan target atau sasaran yang telah ditetapkan. Dengan kata lain dalam dimensi produktivitas ini, aspek yang diutamakan lebih mengarah pada aspek kuantitas.

\section{Efisiensi (Efficiency)}

Menurut Gibson (1986: 34) dimensi efisiensi ini merupakan perbandingan antara keluaran dengan masukan. Sedangkan menurut Handayaningrat (1989: 7) efisiensi berarti penggunaan sarana dan fasilitas kerja (input) yang diperlukan bagi proses pencapaian tujuan yang nilainya relatif lebih kecil dibandingkan dengan besarnya sasaran atau hasil yang dicapai (output). Sementara menurut Han dan Leong (1996 : 131) bahwa efficiency refers to how well the result is acbieved, i.e. producing a piece of quality product in the best possible way (in the shortest time and most cost-effective). Dari pandanganpandangan tersebut terlihat bahwa dimensi efisiensi lebih menunjuk pada aspek kualitas dari hasil yang dicapai atau cara pencapaian hasil tersebut. Dikaitkan dengan variabel penarikan retribusi pasar dalam penelitian ini, maka dimensi efisiensi akan lebih diarahkan pada masalah kualitas dari cara pencapaian sasaran atau target angka penarikan retribusi, baik dari waktu maupun caracara yang digunakan dalam penarikan retribusi pasar.

\section{Kepuasan (Satisfaction)}

Menurut Steers( 1985 : 48) kepuasan berkaitan dengan tingkat kesenangan yang dirasakan seseorang atas peranan atau pekerjaannya. Sementara menurut Wexley dan Yukl (1988 : 160) kepuasan kerja menunjukkan cara pekerja merasakan mengenai pekerjaannya. Kepuasan kerja berkaitan dengan aspek gaji atau upah, kondisi kerja, jaminan kerja dan lain-lain. Dalam kaitannya dengan penarikan retribusi pasar, maka dimensi kepuasan ini menunjuk pada tingkat kesenangan para petugas penarik retribusi dalam menjalankan tugasnya, baik karena situasi internal (gaji, kondisi kerja, teman kerja dan lain-lain) maupun karena situasi eksternal (respon positif masyarakat yang terkena retribusi, sikap peduli dari masyarakat dan lain-lain).

\section{Penyesuaian (Adaptiveness)}

Menurut Gibson (1986: 34) dimensi penyesuaian menunjuk pada tingkat kemampuan melakukan tanggapan atas perubahan-perubahan yang timbul dalam lingkungan, baik internal maupun eksternal. Sedangkan menurut Steers (1985: 48) adaptasi berarti kemampuan untuk mengubah prosedur standar operasi apabila lingkungannya berubah, untuk mencegah kebekuan terhadap rangsangan lingkungan. Melihat pengertian tentang dimensi adaptasi ini terlihat bahwa dimensi menunjuk pada fleksibilitas atau keluwesan dalam menjalankan tugas. Sehubungan dengan fleksibilitas ini, Siagian (1982: 230) mengatakan bahwa Keluwesan dalam menghadapi masalah dan dalam memegang prinsip hidup. Mungkin pepatah yang berkata mundur 
selangkah untuk maju dua langkah, mencerminkan secara tepat apa yang dimaksudkan dengan fleksibilitas.

\section{Pengembangan (Development)}

Menurut Gibson (1986: 35) dimensi pengembangan menunjuk pada kemampuan untuk meningkatkan kapasitasnya dalam menghadapi tuntutan lingkungan. Dalam kaitannya dengan penarikan retribusi pasar dalam penelitian ini, maka dimensi pengembangan diarahkan pada aktivitas-aktivitas untuk meningkatkan kemampuan para petugas penarik retribusi pasar dalam menjalankan tugasnya, baik dalam bentuk penguasaan aturan, prosedur kerja, situasi kerja dan lain-lain.

\section{B. Metode Penelitian \\ Desain Penelitian}

Desain penelitian ditujukan untuk menguji hipotesis penelitian serta melakukan interpretasi mengenai hubungan kausal variabel bebas terhadap variabel tergantung, yaitu variabel kualitas pelayanan dinas pasar (X) dan efektifitas penarikan retribusi parkir $\operatorname{pasar}(\mathrm{Y})$.

\section{Variabel Penelitian}

Penelitian ini dilakukan dengan

menggunakan dua variabel penelitian

(Bivariate), yaitu :

1) Variabel Bebas : Kualitas Pelayanan Dinas Perdagangan dan Perindustrian

2) Variabel Terikat : Efektifitas Penarikan Retribusi Parkir Pasar.

\section{Definisi Operasional}

1) Kualitas pelayanan dinas pasar adalah layanan yang diberikan oleh pemerintah daerah (Dinas Perdagangan dan Perindustrian) yang sesuai atau melebihi persepsi, tuntutan, keinginan, kebutuhan, dan harapan yang menciptakan kepuasan masyarakat (para pengguna parkir). Bila layanan yang diterima atau dirasakan sesuai yang diharapkan, maka kualitas layanan dipersepsikan baik dan memuaskan, sebaliknya bila layanan yang diterima lebih rendah dari yang diharapkan, maka kualitas layanan dipersepsikan buruk.

2) Efektifitas penarikan retribusi parkir pasar adalah tingkat pencapaian tujuan, sasaran atau target dalam penarikan retribusi parkir pasar, baik menyangkut aspek kualitas, kuantitas, waktu, prosedur maupun mekanisme kerjanya.

\section{Populasi dan Sampel}

Populasi dalam penelitian ini adalah masyarakat pengguna parkir di pasar Kota Blitar yang berjumlah rata-rata setiap harinya 880 orang. Untuk menentukan jumlah responden dari sampel digunakan teknik Proportionate Stratifeid Sampling yaitu sejumlah 90 orang.

\section{Instrument Penelitian dan Analisa Data}

Instrument penelitian menggunakan kuesioner dan telah dilakukan uji validitas serta uji reliabilitas. Untuk menguji atau mengukur pengaruh variabel eksogen (exogenous variable) terhadap variabel akibat (endogenous variable), maka digunakan analisis regresi sederahana.

\section{Hasil Dan Implikasi}

Pengambilan data penelitian ini dilaksanakan di Dinas Perdagangan dan Perindustrian Kota Blitar yang mengelola pasar di Kota Blitar yang ditargetkan mendapatkan APD parkir pasar.

\section{Karakteristik responden}

Data karakteristik responden yang terdiri dari distribusi frekuensi berdasarkan berdasarkan jenis kelamin, usia dan pekerjaan.

Tabel 1 Distribusi frekuensi data karakteristik responden

\begin{tabular}{ccc}
\hline Jenis kelamin & F & $\mathbf{\%}$ \\
\hline Perempuan & 43 & 47,8 \\
Laki-Laki & 47 & 52,2 \\
\hline Usia & $\mathbf{F}$ & $\mathbf{\%}$ \\
\hline$<20$ Tahun & 11 & 12,2 \\
$20-30$ tahun & 14 & 15,5 \\
$30-40$ tahun & 24 & 26,6 \\
40-50 tahun & 31 & 34,4 \\
$>50$ tahun & 10 & 11,1 \\
\hline Pekerjaan & $\mathbf{F}$ & $\mathbf{\%}$ \\
\hline Pedagang & 42 & 46,7 \\
Wiraswasta & 13 & 14,4 \\
Pegawai Negeri & 6 & 6,7 \\
TNI/Polri & 4 & 4,4 \\
Lainnya & \multicolumn{3}{c}{ 25 } & 27,7 \\
\hline Berdasarkan tabel & 1 & menunjukkan \\
masyarakat pengguna parkir & di pasar Kota \\
Blitar yang ditarget PAD parkir yang berjenis \\
kelamin laki-laki sebanyak 47 orang $(52,2 \%)$ \\
dan perempuan sebanyak 43 orang (47,8\%). \\
Hal ini menunjukkan bahwa sebagian besar
\end{tabular}


masyarakat pengguna parkir di pasar Kota Blitar adalah laki-laki.

Masyarakat pengguna parkir di pasar Kota Blitar yang ditarget PAD parkir yang berusia kurang dari 20 tahun sebanyak 11 orang $(12,2 \%)$, berusia $20-30$ tahun sebanyak 14 orang $(15,5 \%)$, berusia $30-40$ tahun sebanyak 24 orang $(26,6 \%)$, berusia $40-50$ tahun sebanyak 31 orang $(34,4 \%)$, berusia $>50$ tahun sebnayak 10 orang $(11,1 \%)$. Hal ini menunjukkan bahwa sebagian besar karyawan masyarakat pengguna parkir di pasar Kota Blitar berusia antara 30-50 tahun.

Masyarakat pengguna parkir di pasar Kota Blitar yang ditarget PAD parkir bekerja sebagai pedagang sebanyak 42 orang $(46,7 \%)$, Wiraswasta sebanyak 13 orang $(14,4 \%)$, Pegawai Negeri sebnayak 6 orang $(6,7 \%)$, TNI/Polri sebanyak 4 orang $(4,4 \%)$, dan
Lainnya (swasta, pelajar, dll) sebnayak 25 orang $(27,7 \%)$. Hal ini menunjukkan bahwa sebagian besar masyarakat pengguna parkir di pasar Kota Blitar yang ditarget PAD parkir merupakan pedagang. Pedagang dsini berarti pengguna parkir di pasar merupakan orang yang tidka hanya berbelanja tapi juga menjalankan roda ekonomi untuk keberlangsungan hidupnya.

\section{Variabel Kualitas Pelayanan}

Untuk mengetahui sejauhmana kualitas pelayanan dinas pasar bagi para pedagang, maka akan dianalisis 5 (lima) dimensi kualitas pelayanan publik, yaitu keandalan, ketanggapan, keyakinan, empati dan berwujud, yang akan diuraikan lebih lanjut berdasarkan data yang diperoleh

Tabel 2

Distribusi Skor Rata-Rata Jawaban Responden dan Analisa Regresi

Terhadap Variabel Kualitas Pelayanan

\begin{tabular}{lccccc}
\hline \multicolumn{1}{c}{ Dimensi } & $\begin{array}{c}\text { Rata-rata } \\
\text { skor }\end{array}$ & $\begin{array}{c}\text { Standar } \\
\text { deviasi }\end{array}$ & $\begin{array}{c}\text { Koefisien } \\
\text { regresi }\end{array}$ & Sig. & Ranking \\
\hline Keandalan & 3,8 & 0,46 & 0,226 & 0,000 & 1 \\
\hline Ketanggapan & 3,9 & 0,65 & 0,179 & 0,000 & 5 \\
\hline Keyakinan & 3,7 & 0,77 & 0,198 & 0,000 & 4 \\
\hline Empati & 3,6 & 0,68 & 0,200 & 0,000 & 3 \\
\hline Berwujud & 3,6 & 0,76 & 0,213 & 0,000 & 2 \\
\hline
\end{tabular}

Sumber : Hasil Pengolahan Data, 2018

Dari tabel 2 didapatkan bahwa rata-rata skor jawaban responden terhadap variabel kualitas pelayanan yang paling rendah adalah dimensi empati, berwujud dan keyakinan. Hasil analisa regresi menunjukkan dimensi keandalan, empati dan berwujud merupakan dimensi yang dominan dalam mempengaruhi kualitas pelayanan. Dalam hal ini dimensi keandalan, empati dan berwujud perlu mendapatkan perhatian khusus dalam mendukung kualitas pelayanan sehingga diperlukan strategi untuk meningkatkan pelayanan tersebut.

\section{Variabel Efektivitas Penarikan Retribusi Parkir Pasar}

Analisis terhadap variabel efektivitas penarikan retribusi pasar itu dapat dielaborasi kedalam 5 (lima) dimensinya, yaitu produktifitas kerja, fleksibilitas/adaptasi, kepuasan masyarakat, efisiensi dan pencarian sumber daya. 
Tabel 3

Distribusi Skor Rata-Rata Jawaban Responden dan Hasil Regresi

Terhadap Variabel Efektivitas Penarikan Retribusi Parkir Pasar

\begin{tabular}{lccccc}
\hline \multicolumn{1}{c}{ Dimensi } & $\begin{array}{c}\text { Rata-rata } \\
\text { skor }\end{array}$ & $\begin{array}{c}\text { Standar } \\
\text { deviasi }\end{array}$ & $\begin{array}{c}\text { Koefisien } \\
\text { regresi }\end{array}$ & Sig. & Ranking \\
\hline Produktivitas & 3,8 & 0,56 & 0,213 & 0,000 & 1 \\
\hline Efisiensi & 4,1 & 0,38 & 0,201 & 0,000 & 2 \\
\hline Kepuasan & 3,6 & 0,85 & 0,200 & 0,000 & 3 \\
\hline Penyesuaian & 3,7 & 0,68 & 0,193 & 0,000 & 5 \\
\hline Pengembangan & 3,8 & 0,56 & 0,193 & 0,000 & 4 \\
\hline
\end{tabular}

Sumber : Hasil Pengolahan Data, 2018

Dari tabel 3 didapatkan bahwa rata-rata skor jawaban responden terhadap variabel efektivitas penarikan retribusi parkir pasar yang paling rendah adalah dimensi kepuasan dan penyesuaian. Hasil analisa regresi menunjukkan dimensi produktivitas, efisiensi dan kepuasan merupakan dimensi yang dominan dalam mempengaruhi efektivitas penarikan retribusi. Dalam hal ini dimensi produktivitas, efisiensi dan kepuasan perlu mendapatkan perhatian khusus dalam mendukung efektivitas penarikan retribusi parkir pasar sehingga diperlukan strategi yang efektif dalam mencapai retribusi parkir pasar yang maksimal.

\section{Analisis Regresi}

Untuk menguji ada tidaknya hubungan antara variabel kualitas pelayanan Dinas Perdagangan dan Perindustrian (X) dengan variabel efektifitas penarikan retribusi parkir pasar $(Y)$ serta sejauhmana pengaruh variabel bebas terhadap variabel tergantung harus dilakukan melalui perhitungan statistik. Adapun analisis statistik yang akan dilakukan dalam kaitan dengan penelitian ini adalah analisis regresi sederhana.

Tabel 4

Hasil Pengujian Pengaruh X Terhadap Y

\begin{tabular}{crrrrrr}
\hline $\begin{array}{c}\text { Koefisien } \\
\text { Korelasi }\end{array}$ & $\begin{array}{c}\text { Koefisien } \\
\text { regresi }\end{array}$ & Konstanta & t-hitung & t-tabel & Ket & $\begin{array}{c}\text { Total } \\
\text { Pengaruh }\end{array}$ \\
\hline 0,912 & 0,768 & 0,912 & 20,859 & 1,980 & Sig. & 0,832 \\
\hline
\end{tabular}

Sumber : Hasil Pengolahan Data, 2018

Tabel 4 di atas menunjukkan bahwa variabel kualitas pelayanan Dinas Perdagangan dan Perindustrian (X) dan variabel efektifitas penarikan retribusi parkir pasar $(\mathrm{Y})$ memiliki hubungan yang sangat erat yang ditunjukkan oleh nilai koefisien korelasinya sebesar 0,912. Nilai koefisien korelasi sebesar 0,912 tersebut bila dikonsultasikan pada nilai interpretasi $\mathrm{r}$ dari Guilford, maka berada pada kategori sangat erat. Kemudian untuk mengetahui apakah pengaruh kedua variabel tersebut terjadi secara kebetulan atau bermakna, maka dilakukan uji signifikansi.

Analisis determinasi digunakan untuk mengetahui berapa besar pesentase pengaruh suatu variabel bebas yaitu kualitas pelayanan dinas pasar terhadap variabel tergantung yaitu efektifitas penarikan retribusi pasar. Koefisien ini dihitung dengan cara mengkuadratkan nilai koefisien korelasi dan nilai pengaruh yang diperoleh melalui perhitungan.

Berdasarkan tabel pada lampiran, dapat dijelaskan hasil perhitungan nilai koefisien determinasi dari kedua variabel dalam penelitian ini didapatkan koefisien korelasi antara variabel kualitas pelayanan Dinas Perdagangan dan Perindustrian (X) dengan variabel efektifitas penarikan retribusi parkir pasar (Y) adalah $\operatorname{rxy}=0,912$ dengan determinasi sebesar $(0,912)^{2}=0,832$. Angka ini mengindikasikan bahwa terdapat $83,2 \%$ 
perubahan yang terjadi pada variabel $\mathrm{Y}$ dijelaskan atau ditentukan oleh variabel $\mathrm{X}$.

\section{Pengujian Hipotesis}

Berdasarkan hasil uji signifikansi, maka diperoleh nilai t-hitung sebesar 20,859 lebih besar dari nilai t-tabel sebesar 1,980. Maknanya bahwa pengaruh variabel kualitas pelayanan Dinas Perdagangan dan Perindustrian $(X)$ terhadap variabel efektifitas penarikan retribusi parkir pasar (Y) adalah signifikan. Dalam hal ini maka hipotesis alternatif $\left(\mathrm{H}_{\mathrm{a}}\right)$ diterima sehingga dapat disimpulkan kualitas pelayanan Dinas Perdagangan dan Perindustrian yang meliputi keandalan, ketanggapan, keyakinan, empati dan berwujud berpengaruh secara signifikan terhadap efektifitas penarikan retribusi pasar yang meliputi produktivitas, efisiensi, kepuasan kerja, penyesuaian dan pengembangan di Kota Blitar.

Hasil pengujian secara statistik tersebut memberikan gambaran bahwa untuk mengoptimalkan pendapatan daerah dari sektor retribusi daerah khususnya retribusi parkir pasar, maka salah satu faktor yang harus diperhatikan oleh Pemerintah Kota Blitar adalah memberikan pelayanan yang maksimal kepada masyarakat yang merupakan obyek retribusi parkir pasar. Pentingnya memaksimalkan pendapatan retribusi pasar itu adalah dalam rangka mendukung pembiayaan penyelenggaraan pemerintahan daerah Kota Blitar terutama dalam melaksanakan otonomi daerah yang bertumpu pada kekuatan dan kemampuan keuangan daerah sendiri.

Hasil perhitungan nilai koefisien determinasi dari kedua variabel dalam penelitian ini didapatkan koefisien korelasi antara variabel kualitas pelayanan Dinas Perdagangan dan Perindustrian (X) dengan variabel efektifitas penarikan retribusi parkir pasar $(\mathrm{Y})$ adalah rxy $=0,912$ dengan determinasi sebesar $(0,912)^{2}=0,832$. Angka ini mengindikasikan bahwa terdapat $83,2 \%$ perubahan yang terjadi pada variabel $\mathrm{Y}$ dijelaskan atau ditentukan oleh variabel X.

Dari pengujian determinasi dapat dikatakan bahwa kualitas pelayanan Dinas Perdagangan dan Perindustrian merupakan salah satu faktor yang mempengaruhi variabel efektifitas penarikan retribusi parkir pasar di Kota Blitar. Dengan demikian bahwa jika kualitas pelayanan Dinas Perdagangan dan Perindustrian meningkat, maka efektifitas penarikan retribusi parkir pasar akan meningkat pula, dapat dterima.

\section{Implikasi Hasil Penelitian}

Berdasarkan hasil analisis data yang dilakukan melalui analisis koefisien korelasi, maka diperoleh nilai koefisien korelasi antara kualitas pelayanan dinas pasar dengan variabel efektivitas penarikan retribusi pasar sebesar 0,60. Hal ini menunjukkan bahwa terdapat hubungan yang cukup erat atau moderat antara variabel kualitas pelayanan dinas pasar dengan variabel efektivitas penarikan retribusi pasar. Setelah dilakukan uji signifikansi atau uji kemaknaan diperoleh nilai t-hitung 20,859 lebih besar dari nilai ttabel atau titik kritis yakni 1,980, maka dengan demikian korelasi antara variabel kualitas pelayanan Dinas Perdagangan dan Perindustrian dengan variabel efektivitas penarikan retribusi parkir pasar terjadi secara signifikan atau bermakna. Hasil uji determinasi menunjukkan bahwa besarnya sumbangan variabel kualitas pelayanan dinas pasar terhadap variabel efektivitas penarikan retribusi parkir pasar sebesar 83, $2 \%$, sedangkan $17,8 \%$ dipengaruhi oleh faktor lain yang tidak diteliti dalam penelitian ini.

Hasil penelitian ini memberikan gambaran bahwa kualitas pelayanan Dinas Perdagangan dan Perindustrian merupakan salah satu faktor yang turut menentukan efektivitas penarikan retribusi parkir pasar di Kota Blitar. Mengingat pelayanan publik merupakan fungsi pemerintah yang harus diberikan kepada masyarakat (yang diperintah) dengan sebaik-baiknya. Sementara itu Dinas Perdagangan dan Perindustrian merupakan dinas yang melaksanakan fungsi pemerintah daerah dalam melaksanakan pelayanan publik yakni menyediakan sarana dan prasarana pasar, sedangkan retribusi yang ditarik dari para pedagang merupakan konsekuensi atas jasa sarana dan prasarana yang disediakan oleh pemerintah daerah. Hal ini sebagaimana dikemukakan oleh Budyatna (1996: 22) bahwa retribusi merupakan pungutan sebagai pembayaran atau karena memperoleh jasa pekerjaan, usaha atau milik pemerintah bagi yang berkepentingan atau karena jasa yang diberikan oleh pemerintah, 
dan berdasarkan peraturan yang dibuat oleh pemerintah.

Pentingnya peningkatan kualitas pelayanan yang diberikan oleh Dinas Perdagangan dan Perindustrian kepada para pedagang pasar adalah untuk menciptakan suasana perdagangan yang nyaman, lancar dan memuaskan bagi para pedagang dalam mengelola usahanya maupun mendorong pelaksanaan penerimaan retribusi parkir pasar dalam rangka meningkatkan pendapatan asli daerah bagi Pemerintah Kota Blitar.

Mengingat retribusi parkir pasar bagian dari retribusi daerah yang merupakan salah satu unsur dari pendapatan asli daerah (PAD) yang turut memberikan andil dalam membantu dan mendukung pendanaan penyelenggaraan pemerintahan daerah. Salah satu kendala yang dihadapi oleh pemerintah daerah selama ini adalah bagaimana meningkatkan pendapatan asli daerah terutama dari sektor pajak daerah dan retribusi daerah, sementara itu obyek pajak daerah sangat terbatas. Maka salah satu alternatif dalam pengembangan pendapatan asli daerah adalah dengan mengembangkan dan meningkatkan obyek-obyek retribusi daerah dengan ketentuan adalah meningkatkan kuantitas dan kualitas jasa dan layanan publiknya termasuk layanan pasar bagi pedagang pasar. Karena sangatlah sulit meningkatkan pendapatan dari sektor retribusi parkir pasar tanpa peningkatan kualitas pelayanan pasar kepada para pedagang.

Pemungutan retribusi kepada warga masyarakat dilakukan apabila mereka membutuhkan atau menerima pelayanan atau jasa tertentu. Artinya masyarakat dapat secara sepihak dan sukarela untuk memutuskan apakah akan menggunakan jasa atau suatu usaha yang diselenggarakan oleh pemerintah. Karena terdapat kesukarelaan, maka kualitas jasa atau layanan atau produk yang ditawarkan oleh pihak podusen, dalam hal ini pemerintah, akan sangat menentukan pilihan mamsyarakat untuk memilih menggunakan sesuatu jasa atau layanan pemerintah dan kemudian membayar retribusi atas jasa atau layanan yang diterima tersebut.

Dari pemikiran ini, maka dapat dikatakan bahwa salah satu faktor penentu tingkat efektivitas penarikan retribusi parkir pasar adalah sejauhmana dinas pasar mampu menyelenggarakan pelayanan yang berkualitas yang berkaitan dengan pemanfaatan sarana dan prasarana yang dimiliki akan menentukan sikap dan perilaku masyarakat untuk menggunakan atau menafaatkan jasa tersebut. Secara teoritis dapat dikatakan bahwa semakin tinggi kualitas pelayanan yang dapat diselenggarakan oleh Dinas Perdagangan dan Perindustrian, maka semakin tinggi pula efektivitas penarikan retribusi pasar oleh dinas pasar. Dan sebaliknya semakin rendah atau buruk kualitas pelayanan oleh Dinas Perdagangan dan Perindustrian, bisa diduga akan semakin sulit bagi Dinas Perdagangan dan Perindustrian untuk meningkatkan efektivitas penarikan retribusi parkir pasar. Lebih jauh kemudian dapat dikatakan bahwa apabila semakin sulit kemampuan Dinas Perdagangan dan Perindustrian untuk melakukan penarikan retribusi parkir pasar, maka akan semakin terbatas pendapatan asli daerah (PAD) yang dapat diperoleh, dan itu berarti akan semakin terbatas kemampuan daerah dalam menyediakan sumber daya keuangan untuk menggerakkan roda pembangunan dan pemerintahan di daerah. Ini semua menunjukkan betapa penting dan strategisnya masalah kualitas pelayanan yang dilakukan oleh Dinas Perdagangan dan Perindustrian, pada khususnya maupun bagi penyelenggaraan pemerintahan daerah pada umumnya.

\section{Kesimpulan dan Rekomendasi Simpulan}

Berdasarkan analisa pengaruh kualitas pelayanan Disperindag berpengaruh terhadap efektifitas penarikan retribusi parkir pasar di Kota Blitar didapatkan nilai t-hitung sebesar 20,859 lebih besar dari nilai t-tabel sebesar 1,980. Dalam hal ini maka hipotesis alternatif $\left(\mathrm{H}_{\mathrm{a}}\right)$ diterima sehingga dapat disimpulkan kualitas pelayanan Dinas Perdagangan dan Perindustrian yang meliputi keandalan, ketanggapan, keyakinan, empati dan berwujud berpengaruh secara signifikan terhadap efektifitas penarikan retribusi pasar yang meliputi produktivitas, efisiensi, kepuasan kerja, penyesuaian dan pengembangan di Kota Blitar. Nilai koefisien determinasi dari kedua variabel dalam penelitian ini didapatkan koefisien korelasi antara variabel kualitas pelayanan Dinas Perdagangan dan Perindustrian (X) dengan 
variabel efektifitas penarikan retribusi parkir pasar (Y) adalah rxy $=0,912$ dengan determinasi sebesar $(0,912)^{2}=0,832$. Angka ini mengindikasikan bahwa terdapat $83,2 \%$ perubahan yang terjadi pada variabel $\mathrm{Y}$ dijelaskan atau ditentukan oleh variabel $\mathrm{X}$. Dari pengujian determinasi dapat dikatakan bahwa kualitas pelayanan Dinas Perdagangan dan Perindustrian merupakan salah satu faktor yang mempengaruhi variabel efektifitas penarikan retribusi parkir pasar di Kota Blitar.

\section{Rekoemndasi}

Sesuai dengan kesimpulan yang telah dikemukakan, peneliti ingin memberikan beberapa saran kepada Pemerintah Kota Blitar khsususnya Dinas Perdagangan dan Perindustrian untuk meningkatkan kualitas maupun kuantitas sarana dan prasarana pasar dan parkirnya, sehingga para pedagang dapat menjalankan usahanya secara maskimal dan konsumen nyaman untuk berbelanja di pasar tradisional Dengan terpenuhinya berbagai sarana dan prasarana pasar tersebut, maka masyarakat merasa selalu diperhatikan kebutuhannya oleh pemerintah daerah, maka mereka tidak keberatan dalam membayar retribusi atas jasa atau layanan yang mereka gunakan dari pemerintah daerah.

\section{E. Daftar Pustaka}

"Peraturan Pemerintah Nomor 20 tahun 1997 tentang Retribusi Daerah “.

Davey, K J, 1998, Pembiayaan Pemerintah Daerah: Praktek-Praktek Internasional dan Relevansi bagi Dunia Ketiga, Universitas Indonesia Press, Jakarta,

Departemen Dalam Negeri, 1997, Pajak Daerah dan Retribusi Daerah, UU No. 18 Cetakan Pertama, Harvanindo, Jakarta.

Departemen Dalam Negeri, 1999, Pemerintahan Daerah, UU No. 22, Jakarta.

Devas et al, 1989, Kenangan Pemerintah Daerah di Indonesia, (terjemahan oleh Masri Maris), UI-Press, Jakarta

Dewanto, Wahyu, 2001, "Peranan Retribusi Pasar Dalam Otonomi Daerah dan Faktor-faktor Yang Mempengaruhinya", Tesis S-2 Program Pasca sarjana Universitas Gadjah Mada, Yogyakarta (tidak dipublikasikan)
Downing, P.B. 1992, “The Revenue Potential Of User Charges In Municipal Finance ", Publik Finance Quarterly, Vol. 20 No. 4, 512-527.

Gasperz, Vincent. 2003. Total Quality Manajement. Gramedia Pustaka Utama. Jakarta.

Insukindro dkk, 1994, "Peran dan Pengelolaan Keuangan Daerah Dalam Usaha Peningkatan PAD", Laporan Penelitian. KKD, FE-UGM, Yogyakarta.

Jones, Rowan and Pendlebury, Maurice, 1996, Public Sector Accounting, London, Pitman Publishing.

Kaho, Joseph Riwu, 2005. "Prospek Otonomi Daerah di Negara Kesatuan Republik Indonesia", Jakarta: Raja Grafindo Persada.

Kambu, Manase Robert, 2000, "Kajian Potensi dan Proyeksi Retribusi Pasar serta kontribusinya Terhadap Penerimaan Asli Daerah di Kotamadya Jayapura ", Tesis S-2 Program Pascasarjana Universitas Gadjah Mada, Yogyakarta (tidak dipublikasikan).

Kim, Sung Tai, 1997, “The Role Of Local Public Sector In Regional Economic Growth In Korea ", Asian Economic Journal, Vol 11 No. 21, 155-168.

Koswara, E, 2000, Menyongsong Pelaksanaan Otonomi Daerah Berdasarkan Undang-undang Nomor 22 Tahun 1999, Analisis CSIS, Tahun XXIX/2000 No. 1.36-53.

Mahi, Raksaka, 2000, "Prospek Desentralisasi di Indonesia Ditinjau Dari Segi Pemerataan Antar Daerah dan Peningkatan Efisiensi ", Jurnal CSIS, No. $154-56$

Mardiasmo \& Akhmad Makhfatih, 2000, Pengitungan Potensi Pajak Daerah dan Retribusi Daerah di Kabupaten Magelang, Modul Pelatihan, PAU Studi Ekonomi UGM, Yogyakarta.

Miller, Stephen M. Dan Frank s. Russek, 1997, “Fiscal Structures and Economic Growth at The State and Local Level". Public Finance Review, Vol 25, No. 2, 213 237.

Munawir, S, 1999, Perpajakan, Liberty, Edisi Kelima Cetakan Kedua, Yogyakarta.

PAU-SE UGM 2000, Penghitungan Potensi Pajak dan Retribusi Daerah di Kabupaten Magelang, Pemda Kabupaten Magelang 
Kerjasama dengan Pusat Antar Universitas-Studi Ekonomi Universitas Gadjah Mada, Yogyakarta (tidak dipublikasikan).

Santoso, Bagus, 1995, “ Retribusi Pasar Sebagai Pendapatan Asli Daerah, Studi Kasus Pasar Kabupaten Sleman, " Prisma Nomor 4 , LP3ES 19-35.

Siddik, Machfud, 2002, “ Hubungan Kenangan Pemerintah Pusat dan Daerah Yang Mengacu Pada Pencapaian Tujuan Nasional ", Seminar Nasional Public Sector Scorecard, Jakarta.

Soelarti, 1997, "Faktor-faktor Yang Mempengaruhi Penerimaan Retribusi Pasar Dalam Upaya Peningkatan PAD di Kabupaten Daerah Tingkat II Indramayu “, Tesis S-2, Program Pascasarjana Universitas Gadjah Mada Yogyakarta (tidak dipublikasikan).

Soeratno dan Lincoln Arsyad, 2008, "Metodologi Penelitian Untuk Ekonomi dan Bisnis, , UPP AMP YKPN, Yogyakarta.

Sudarmadji, 2000, “ Analisis Efisiensi, Efektivitas dan Prospek Pungutan Retribusi Pasar di Kabupaten Sorong," Tesis S-2 Program Pascasarjana Universitas Gadjah Mada, Yogyakarta (Tidak Dipublikasikan).

Syamsi, Ibnu, 1994, Dasar-dasar Kebijaksanaan Keuangan Negara, Cetakan Ketiga, PT Rineka Cipta, Jakarta.

Tjiptono, Fandi. 2011, Pemasaran Jasa, Bayumedia, Malang.

Undang-undang Republik Indonesia Nomor 22 tahun 1999 tentang "Pemerintahan Daerah," Dirjen PUOD, Jakarta.

Undang-undang Republik Indonesia Nomor 25 tahun 1999 tentang "Perimbangan Kenangan antara Pemerintah Pusat dan Daerab", Direktorat Jenderal PUOD, Jakarta.

Widodo, H G Suseno $\mathrm{T}$ 1991, Indikator Ekonomi Dasar Perbitungan Perekonomian Indonesia, Kanisius, Yogyakarta.

Yandhi, G, 1996, “ Kinerja Efektifitas dan Efisiensi Pemungutan Pajak Pembangunan I di Kotamadya Daerah Tingkat II Banjarmasin, 1991/19921995/1996 “, Tesis S-2, Program Pascasarjana (tidak dipublikasikan). 